\title{
Dynamics of rotifer and cladoceran resting stages during copper pollution and recovery in a subalpine lake
}

\author{
Roberta Piscia $^{1 *}$, Piero Guilizzoni ${ }^{1}$, Diego Fontaneto ${ }^{2}$, Davide A.L. Vignati ${ }^{3}$, Peter G. Appleby ${ }^{4}$ \\ and Marina Manca ${ }^{1}$ \\ 1 CNR ISE Largo Tonolli 50, 28922 Verbania, Italy \\ 2 Division of Biology, Imperial College London, Silwood Park Campus, Ascot Berkshire SL5 7PY, UK \\ ${ }^{3}$ CNR IRSA, UOS Brugherio, Via del Mulino 19, 20047 Brugherio (MB), Italy \\ ${ }^{4}$ Environmental Radioactivity Research Centre, Mathematical Sciences Building, University of Liverpool, Liverpool L69 7ZL, UK
}

Received 13 April 2011; Accepted 11 January 2012

\begin{abstract}
Despite their ecological importance and ability to react to environmental changes, including pollution, monogonont rotifers have never been used in palaeolimnological studies because they do not leave subfossil remains. In this study, we tested the possibility of using rotifer resting eggs as a proxy for reconstruction of changes in biodiversity during chronic copper pollution and recovery of a deep sudalpine lake (Lake Orta, Italy). The lake was selected owing to a rich history of previous studies that explored species-specific responses to environmental stressors. Rotifer-based results were compared with those on ephippia and on previously investigated Cladocera subfossil remains. Responses of Rotifera resting eggs to environmental changes were clear and consistent with those previously observed on Cladocera. The abundance of resting eggs increased during pollution, and new morphotypes appeared in addition to those already present. However, overall diversity decreased sharply, as a few morphotypes became dominant. Resting eggs of Brachionus calyciflorus as old as ca. 100 years were still fully viable; viability was not affected by toxic conditions of the environment in which the eggs were produced. Over a period of $c a .80$ years, all resting eggs of B. calyciflorus belonged to a single clone, the most widely distributed one in North America. Cladocera ephippia started to accumulate later and at a lower level of abundance than rotifer resting eggs. Overall, Cladocera ephippia were, however, less effective than rotifers in tracing lake historical changes. The results point out at the great potential of using rotifer resting eggs in palaeolimnological reconstructions.
\end{abstract}

Key words: Biodiversity / Cladocera / rotifer resting eggs / copper pollution / recovery

\section{Introduction}

Monogonont rotifers are often a numerically dominant component of zooplankton communities, and respond quickly to environmental stresses including changes in lake trophy, predation pressure and climate (Kirk, 1997). Differently from Cladocera, Monogonont rotifers do not form subfossil remains; therefore, they have not been used in palaeolimnological studies (Frey, 1986; Jeppesen et al., 2003; Sarmaja-Korjonen, 2004; Nevalainen et al., 2011). They are, however, able to produce resting eggs, which are preserved in lake sediments and which exhibit a great variety of structural variation. This variation can be exploited to allow for an identification of different morphotypes (Koste, 1978), thus enabling a

\footnotetext{
*Corresponding author: r.piscia@ise.cnr.it
}

reconstruction of changes in diversity and abundance in sediment cores.

Production of resting eggs is promoted by different mechanisms, some of which are species-specific. The same species may also produce different morphotypes of eggs (e.g., female polymorphism and sexual reproduction; Sudzuki, 1964; Gilbert, 1974), making it difficult to link resting eggs' diversity to species diversity. In some cases, however, intraspecific polymorphism has been linked to environmental conditions, such as the presence of dietary tocopherol (Gilbert, 1980) and/or population density levels (Gilbert and Schröder, 2004), suggesting that it might be possible to use them as a proxy-record for changes in diversity.

In this study, we reconstruct changes in abundance, morphological and genetic diversity, and in viability, of monogonont rotifer resting eggs as part of a 
palaeolimnological study, with the aim of investigating whether and how pollution and recovery were also detectable in the lacustrine Rotifera community. In particular, we hypothesized that an increase in production of resting eggs and a decrease in diversity and a selection of morphotypes/clones able to survive would occur under the unfavorable conditions associated with chronic pollution stress. We also tested whether egg viability was affected by long-term exposure to pollutants in the sediments in which they were preserved.

To test these hypotheses, we selected an environment (Lake Orta) with a well-known history of chronic copper pollution, which had been investigated during pollution as well as in the pre- and post-pollution phases (Bonacina and Baudo, 2001). Observational data on this lake have been complemented by palaeolimnological studies, thus allowing for a comparative analysis of response mechanisms by plankton and benthic organisms to environmental stress. In particular, data on Monogononta resting eggs from this study are compared with data on planktonic Cladocera reconstructed from previously analyzed subfossil remains (Manca and Comoli, 1995).

\section{Study site}

Located in the Italian subalpine region, Lake Orta is a deep $\left(Z_{\max }=143 \mathrm{~m}, \bar{z}=71 \mathrm{~m}\right)$, warm, oligo-monomictic lake. It became chronically polluted after a rayon factory was established at the southern end of the lake in 1926, discharging huge amounts of copper and ammonium sulfate into the water (Calderoni et al., 1990). The biochemical oxidation of $\mathrm{N}-\mathrm{NH}_{4}$ caused nitrate $\left(\mathrm{N}-\mathrm{NO}_{3}\right)$ accumulation and a strong decrease in the $\mathrm{pH}$ of the lake, which was poorly buffered due to geology of the catchment. Copper concentration in the water column also increased, reaching a maximum of $108 \mu \mathrm{g} . \mathrm{L}^{-1}$ in 1958 (value at the winter overturn). From 1958 on, $\mathrm{Cu}$ was recovered from the factory effluent prior to discharge into the lake. Ammonium discharge stopped in 1980 when a law regulating discharge of industrial wastes into freshwater environments was established in Italy.

Zooplankton reacted promptly to the improvements in water quality. Rotifers were the first colonizers (Brachionus calyciflorus, Brachionus urceolaris, Hexarthra fennica and Asplanchna brigthwellii) followed by the planktonic Cladocera. The gradual colonization was accompanied by remarkable changes in zooplanktonic community structure and size (Manca and Comoli, 1995; Cattaneo et al., 1998).

\section{Materials and methods}

To detect changes in production and viability of resting eggs of Rotifera and Cladocera during and after copper pollution of Lake Orta, a 52.5-cm-long sediment core (ORTA 07/1A) was collected during 2007 with a gravity corer (inner diameter $=6.3 \mathrm{~cm}$ ) at a station located near the rayon factory in the south basin of the lake (depth
$31 \mathrm{~m}$; Fig. 1). The core was stored in the dark at $4{ }^{\circ} \mathrm{C}$, then opened and cut longitudinally for visual inspection, lithological description and sub-sampling into $1 \mathrm{~cm}$ slices. The topmost $6 \mathrm{~cm}$ of the sediment core was cut every $1 \mathrm{~cm}$, while the rest of the core - comprised mainly of clastic and stratigraphically homogeneous material - was sliced at every $5 \mathrm{~cm}$ intervals. A total of 15 subsamples were analyzed.

Water and organic matter content (LOI; loss on ignition) were analyzed to detect changes in sediment composition during pre-pollution (before 1926), pollution (1926-1989) and recovery (post-1989) phases. Radionuclides $\left({ }^{210} \mathrm{~Pb},{ }^{226} \mathrm{R}\right.$ and $\left.{ }^{137} \mathrm{C}\right)$ were analyzed to establish radiometric dating, while copper concentration was measured to allow comparison with historical data based on water column (0-140 m depth) samples. We also extracted resting stages to run viability tests of monogonont rotifers, and conducted genetic identification of strains for the most common taxa.

On each sample, we measured water content and LOI in duplicate, by weight loss after ignition at 60 and $550{ }^{\circ} \mathrm{C}$, respectively (Dean, 1974). Dating of the sediment core was performed by analyzing ${ }^{210} \mathrm{~Pb},{ }^{226} \mathrm{R}$ and ${ }^{137} \mathrm{Cs}$ by direct gamma assay in the Liverpool University Environmental Radioactivity Laboratory, using Ortec HPGe GWL series well-type coaxial low-background intrinsic germanium detectors (Appleby et al., 1986). ${ }^{210} \mathrm{~Pb}$ was determined via its gamma emissions at $46.5 \mathrm{keV}$ and ${ }^{226} \mathrm{Ra}$ by the 295 and $352 \mathrm{keV} \gamma$-rays emitted by its daughter isotope ${ }^{214} \mathrm{~Pb}$ following 3 weeks storage in sealed containers to allow radioactive equilibration. ${ }^{137} \mathrm{Cs}$ was measured by its emissions at $662 \mathrm{keV}$. The absolute efficiencies of the detectors were determined using calibrated sources and sediment samples of known activity. Corrections were made for the effect of self-absorption of low-energy $\gamma$-rays within the sample (Appleby et al., 1992). Unsupported ${ }^{210} \mathrm{~Pb}$ activities were calculated by subtracting ${ }^{226} \mathrm{Ra}$ activities from total ${ }^{210} \mathrm{~Pb}$ activity. Radiometric dates were calculated using standard (Constant Rate of Supply (CRS); and Constant Initial Concentration (CIC)) ${ }^{210} \mathrm{~Pb}$ dating models (Appleby and Oldfield, 1978) and the results compared wherever possible with stratigraphic dates determined from the ${ }^{137} \mathrm{Cs}$ record. A best chronology for the core was determined using the procedures described in Appleby (2002).

Changes in copper concentration in the water column before and during the pollution phase and into the recovery phase were based on published and unpublished data (Calderoni and Tartari, 2001). Copper content from surface to bottom was measured by Atomic Absorption Spectrophotometry (AAS) (GAAS Perkin Elmer) at the deepest point (Qualba) station during winter mixing (Fig. 1). Copper pollution was also measured from the sediment core using AAS (GF-AAS) with a Perkin Elmer A Analyst 600 with Zeeman correction, equipped with a graphite atomization system, after microwave-assisted digestion (Milestone MLS 1200) of dried samples (0.1 g) with $5 \mathrm{~mL}$ of concentrated $\mathrm{HNO}_{3}$ acid (VWR, Suprapur). Procedural blanks were regularly run to check for ambient or reagent contamination and the accuracy of $\mathrm{Cu}$ recovery 


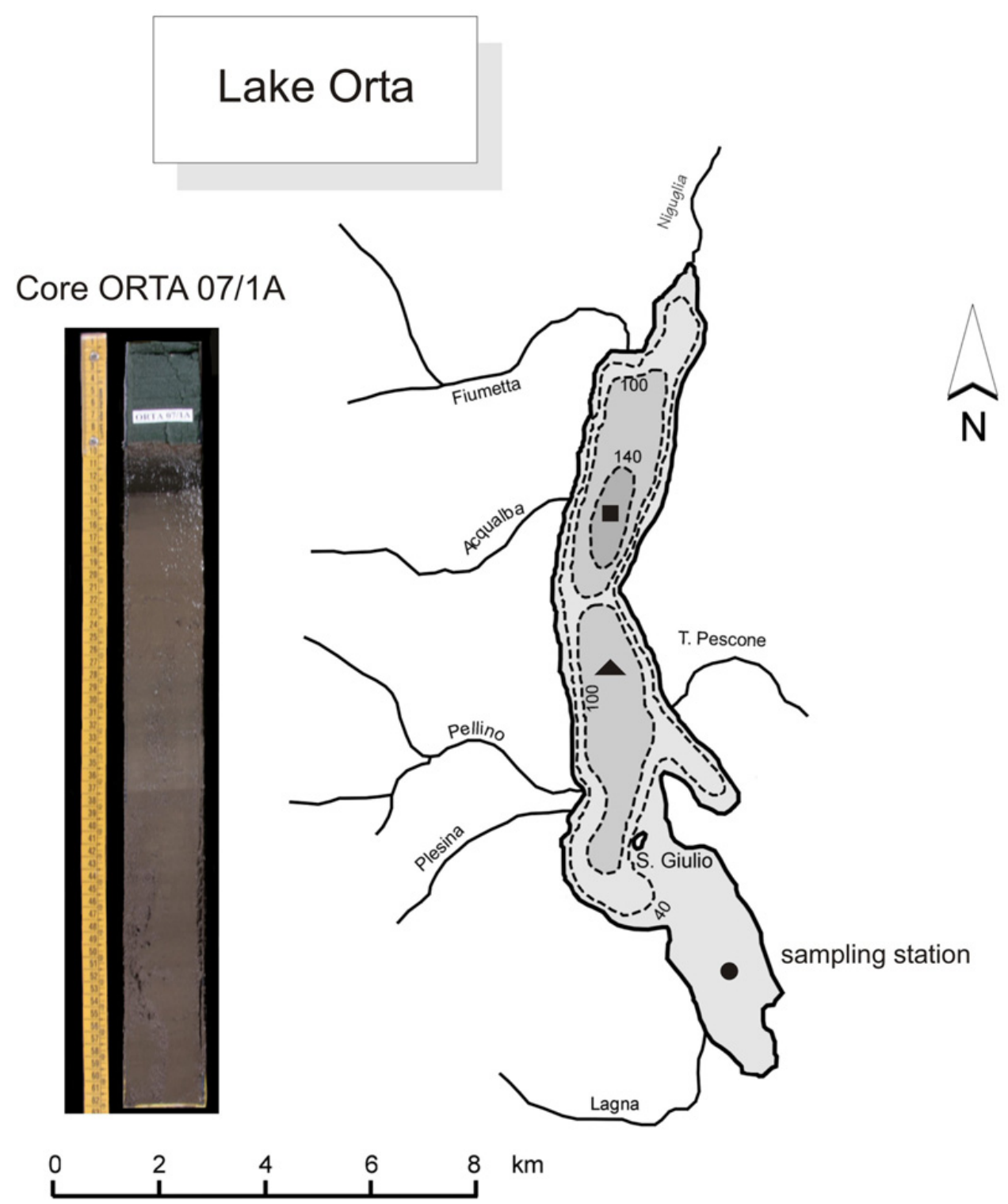

Fig. 1. Map of Lake Orta and photograph of core ORTA 07/1A collected at the south end of the lake (•) in 2007. The Qualba Station, from which samples for copper water concentration were collected, is shown ( $\mathbf{\square})$. The station from which ORTA 94 sediment core was collected is also shown (A).

from sediment samples was $97 \pm 19 \%(n=4)$ as estimated using reference material S7 (Aquacon project CHECK) with a certified $\mathrm{Cu}$ content of $100 \pm 2 \mathrm{mg} \cdot \mathrm{kg}^{-1}$.

Analyses of the resting stages of rotifers and Cladocera were performed after extraction (sediment, $c a .20 \mathrm{~g}$ wet weight (w.w.)) with a saturated, water-sugar solution (Onbé, 1978) and resuspension into oligomineral water $\left(21.7 \mu \mathrm{S} . \mathrm{cm}^{-1}\right)$. Each sample was analyzed in its entirety. Egg counts were performed at 63 times magnification. Rotifer resting eggs were identified on the basis of size, shape and sculptures (after Koste, 1978) at a magnification of $400 \times$. In addition, we checked randomly subsamples of the precipitate to verify that extraction of resting stages was complete.

To trace changes in production of resting stages, we isolated and distinguished all full and empty egg cases.
Data were expressed as accumulation rates $\left(\right.$ eggs. $\mathrm{m}^{-2}$.year ${ }^{-1}$ ) on the basis of sedimentation rates (cf. Table 1) calculated from dating. We compared changes in diversity based on data for rotifers with those previously analyzed for zooplankton Cladocera subfossil remains, (core ORTA/94; Manca and Comoli, 1995) (ShannonWeaver's $H$ index expressed as $\log _{2}$, and evenness) (Shannon and Wiener, 1963; Pielou, 1966). Mean annual diversity of the live rotifer community was calculated for 1989 and 2001 from monthly integrated samples for the upper $50 \mathrm{~m}$, collected at Qualba (unpublished data provided by C. Bonacina-CNR-ISE; Fig. 1).

Egg viability was tested on samples from the topmost $6 \mathrm{~cm}$ of the core (last $c a .100$ years), as eggs from deeper sections were deemed too old ( $>300$ years) to remain viable (Hairston et al., 1995). Recovered Rotifera resting 
Table $1 .{ }^{210} \mathrm{~Pb}$ chronology of the sediment core ORTA $07 / 1 \mathrm{~A}$.

\begin{tabular}{|c|c|c|c|c|}
\hline \multirow[b]{2}{*}{ Depth $(\mathrm{cm})$} & \multicolumn{2}{|c|}{ Chronology } & \multicolumn{2}{|c|}{ Sedimentation rate } \\
\hline & Date (AD) & Age (years) & g.cm $^{-2} \cdot$ year $^{-1}$ & cm.year $^{-1} \pm \%$ \\
\hline 0.0 & 2007 & $0 \pm 0$ & & \\
\hline 0.5 & 2001 & $6 \pm 2$ & 0.0092 & $0.083 \pm 9.0$ \\
\hline 1.5 & 1989 & $18 \pm 3$ & 0.0144 & $0.077 \pm 13.2$ \\
\hline 2.5 & 1975 & $32 \pm 4$ & 0.0115 & $0.063 \pm 17.1$ \\
\hline 3.5 & 1957 & $50 \pm 5$ & 0.0078 & $0.050 \pm 14.7$ \\
\hline 4.5 & 1935 & $72 \pm 7$ & 0.0078 & $0.041 \pm 14.7$ \\
\hline 5.5 & 1909 & $98 \pm 11$ & 0.0078 & $0.033 \pm 14.7$ \\
\hline
\end{tabular}

Table 2. Fallout radionuclide concentrations in sediment core ORTA 07/1A.

\begin{tabular}{lcccrc}
\hline & \multicolumn{4}{c}{${ }^{210} \mathrm{~Pb}$} \\
\cline { 2 - 5 } Depth $(\mathrm{cm})$ & Dry mass $\left(\mathrm{g} . \mathrm{cm}^{-2}\right)$ & $\begin{array}{c}\text { Total } \\
\text { Bq.kg }\end{array}$ & $\begin{array}{c}\text { Unsupported } \\
\text { Bq.kg }\end{array}$ & $\begin{array}{c}\text { Supported } \\
\text { Bq.kg }^{-1}\end{array}$ \\
\hline 0.5 & 0.1 & $2140.9 \pm 101.6$ & $2044.0 \pm 103.4$ & $96.9 \pm 19.1$ & $473.4 \pm 19.7$ \\
1.5 & 0.2 & $1007.3 \pm 70.8$ & $891.8 \pm 72.4$ & $115.5 \pm 15.5$ & $535.6 \pm 16.9$ \\
2.5 & 0.4 & $836.6 \pm 58.3$ & $735.0 \pm 59.8$ & $101.6 \pm 13.3$ & $411.4 \pm 14.3$ \\
3.5 & 0.5 & $772.2 \pm 79.7$ & $656.3 \pm 80.8$ & $115.9 \pm 13.5$ & $376.6 \pm 17.1$ \\
4.5 & 0.7 & $386.4 \pm 29.9$ & $307.7 \pm 30.7$ & $78.7 \pm 7.1$ & $168.7 \pm 7.7$ \\
5.5 & 0.9 & $184.2 \pm 22.6$ & $108.2 \pm 23.3$ & $76.0 \pm 5.4$ & $62.7 \pm 5.2$ \\
10.5 & 2.1 & $76.3 \pm 6.6$ & $2.3 \pm 9.3$ & $73.9 \pm 6.5$ & $0.0 \pm 0.0$ \\
15.5 & 3.5 & $76.4 \pm 7.3$ & $-2.5 \pm 9.7$ & $78.8 \pm 6.4$ & $4.2 \pm 3.9$ \\
\hline
\end{tabular}

eggs and Cladocera ephippia were kept in multi-well plates with oxygenated water, and were stored in the dark at $4{ }^{\circ} \mathrm{C}$ before being incubated in a thermostatic cell at a light intensity of $2.8-3.3 \times 10^{3}$ Lux, a photoperiod of $16 \mathrm{~h}$ light: $8 \mathrm{~h}$ dark and a constant temperature of $20^{\circ} \mathrm{C}$, to induce hatching. Hatchlings were recorded every $24 \mathrm{~h}$ until day 14 of the experiment.

Genetic analyses were performed from the topmost 6 $\mathrm{cm}$ of the core on resting eggs of the most common Brachionus sp., which was present throughout Lake Orta's pollution and recovery phases. A total of 29 resting eggs were analyzed, mainly collected from 1-2 to 4-5 cm layers, where eggs were most commonly encountered, with only a single egg selected from the 5-6 cm layer. Eggs were preserved in $96 \%$ ethanol. Prior to extraction, each resting egg was put in a $0.5 \mathrm{~mL}$ tube and dehydrated; DNA extraction was performed by adding $35 \mu \mathrm{L}$ of Chelex (InstaGene Matrix, Bio-Rad) and incubating for $20 \mathrm{~min}$ at $56^{\circ} \mathrm{C}$ and $10 \mathrm{~min}$ at $100^{\circ} \mathrm{C}$. A part of the cytochrome c oxidase subunit I (COI) gene was PCR-amplified using optimized primers LCOI (50-GGT CAA CAA ATC ATA AAG ATA TTG-30) and HCOI (50-TAA ACT TCA GGG TGA CCA AAA AAT C-30) (Folmer et al., 1994). Cycle conditions comprised initial denaturation at $94^{\circ} \mathrm{C}$ for $5 \mathrm{~min}$, followed by 40 cycles at $94{ }^{\circ} \mathrm{C}$ for $40 \mathrm{~s}, 50{ }^{\circ} \mathrm{C}$ for $1 \mathrm{~min}$ and $72^{\circ} \mathrm{C}$ for $40 \mathrm{~s}$, after which a final extension step at $72{ }^{\circ} \mathrm{C}$ was kept for $7 \mathrm{~min}$. Cycle sequencing reactions were set up using PCR primers and the ABI Big Dye Terminator v1.1 kit, and run on an ABI 3770 automated sequencer. The sequences were checked and assembled using FINCHTV 1.4.0 (http://www.geospiza.com/finchtv) and aligned and edited by eye with a text editor.

\section{Results}

\section{Core chronology}

Age control was based on ${ }^{210} \mathrm{~Pb}$ dating. Total ${ }^{210} \mathrm{~Pb}$ activity reached an equilibrium with that of the supporting ${ }^{226} \mathrm{Ra}$ at a depth of between 6 and $10 \mathrm{~cm}$ (Table 2). Unsupported ${ }^{210} \mathrm{~Pb}$ concentrations declined steeply and more or less exponentially with depth, apart from a small feature between 1.5 and $3.5 \mathrm{~cm}$, where the gradient of decline was somewhat shallower.

${ }^{137} \mathrm{Cs}$ concentrations had their highest values in the $1-2$ $\mathrm{cm}$ sample. This feature most probably records fallout from the 1986 Chernobyl accident. Fallout from this source, confirmed by the presence of the associated shortlived isotope ${ }^{134} \mathrm{Cs}$, was detected in the surficial sediments of an earlier core from this lake collected in the 1990s. Although downward diffusion from the Chernobyl fallout appears to have partially masked the record of fallout from atmospheric testing of nuclear weapons, the rise in ${ }^{137} \mathrm{Cs}$ concentrations between 4.5 and $3.5 \mathrm{~cm}$ is consistent with increased levels of fallout from the latter source during the late 1950s and early 1960s. The shoulder on the ${ }^{137} \mathrm{Cs}$ profile at $2.5-3.5 \mathrm{~cm}$ is also consistent with the fallout maximum nuclear weapons testing in 1963.

${ }^{210} \mathrm{~Pb}$ dates calculated using the CRS model were more consistent than those determined using the CIC model, and in relatively good agreement with the ${ }^{137} \mathrm{Cs}$ record, placing 1986 at a depth of between 1.5 and $2 \mathrm{~cm}$, and 1963 between 3 and $3.5 \mathrm{~cm}$ (Fig. 2). They were therefore used as the basis for the core chronology (see Table 1). It appears from these results that dry mass sedimentation rates were 


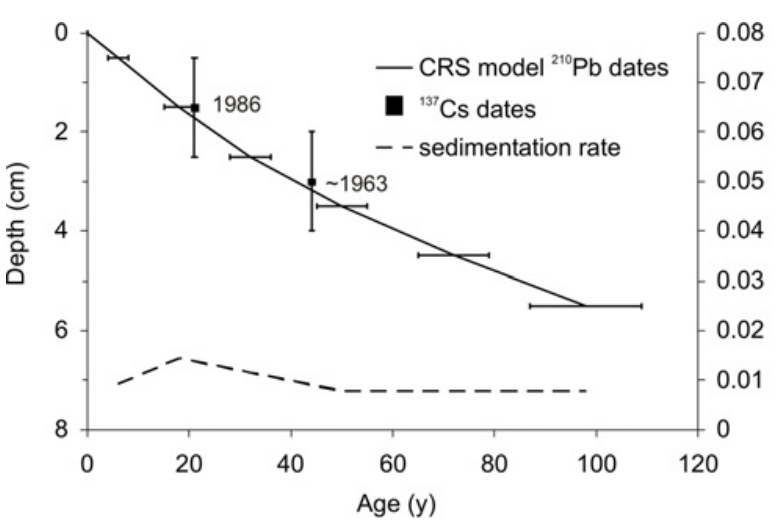

Fig. 2. Radiometric chronology of the sediment core ORTA 07/ $1 \mathrm{~A}$ showing the CRS model ${ }^{210} \mathrm{~Pb}$ dates and sedimentation rates together with the 1986 depth and approximate 1963 depth determined from the ${ }^{137} \mathrm{Cs}$ stratigraphy.

relatively constant during much of the 20th century, apart from a brief episode of accelerated sedimentation in the late 1970 s or early 1980s. Excluding this episode, the mean (volumetric) sedimentation rate was calculated to be 0.041 $\mathrm{cm}_{\text {.year }}{ }^{-1}$. A lower rate of $0.033 \mathrm{~cm}_{\text {.year }}{ }^{-1}$ for pre- 1900 sediments, calculated by assuming a constant (dry mass) sedimentation rate of 0.0078 g.cm ${ }^{-2}$.year ${ }^{-1}$, is mainly due to compaction of older material.

The sediment core stratigraphy exhibited a homogenous lithology with only two distinctly separated zones (Fig. 1). The topmost $4 \mathrm{~cm}$ of the core was dark and organically rich. Below the $2 \mathrm{~cm}$ section, the percentage of organic matter (LOI) was quite constant on $c a .15 \%$ dry weight (d.w.), while above $2 \mathrm{~cm}$, it increased to $25 \%$ d.w. (Fig. 1). Dry weight slightly increased from the bottom to the $25 \mathrm{~cm}$ sediment section, where it approached a maximum of $31 \%$ d.w., before decreasing in the uppermost section $(15 \%$ d.w.). Using the basal sedimentation rate $\left(0.033 \mathrm{~cm}_{\text {.year }}{ }^{-1}\right)$ and given the homogenous sediment stratigraphy, an approximate age of 1400 AD was estimated for the core bottom. Pre-1800 dates were based on a linear extrapolation, consistent with the lack of major changes in LOI and sedimentation rates observed in this (and other cores analyzed previously) period.

\section{Copper pollution}

The profile of total copper concentrations in the ORTA 07/1A sediment core matched very well that measured in the water column between 1926 and 2007 (Fig. 3). In the water compartment, $\mathrm{Cu}$ concentrations increased until 1958, when a maximum of $108 \mu \mathrm{g} . \mathrm{L}^{-1}$ was measured during winter mixing. Cu concentrations decreased thereafter due both to a reduction in discharge of this pollutant and to liming of the lake during the late 1980s (Calderoni et al., 1990).

We observed a progressive accumulation of $\mathrm{Cu}$ in lake sediment, with a maximum of $3.6 \mathrm{mg} \cdot \mathrm{g}^{-1}$ (dry weight) in the 3-4 cm section, corresponding with $1957 \pm 5$. Copper concentration was also high $\left(\mathrm{Cu}=1.3 \mathrm{mg} \cdot \mathrm{g}^{-1} \mathrm{~d} . \mathrm{w}\right.$. $)$ in the recently deposited $0-1 \mathrm{~cm}$ sediment section.

\section{Resting stages}

Resting eggs of both Cladocera and rotifers were detected at $20-21 \mathrm{~cm}$ of the sediment core (corresponding to $c a$. 600 years ago; Fig. 3, panels 3 and 4), indicating a preservation date in the sediment of $c a .1400$ AD. Accumulation of rotifer resting eggs began to increase (up to $7.6 \times 10^{3}$ eggs.m ${ }^{-2}$.year ${ }^{-1}$ ) in the $4-5 \mathrm{~cm}$ section $(72 \pm 7$ years BP), during the phase of intense copper pollution, when ammonium concentration was still low and water pH close to neutrality (Fig. 3, panels 1 and 2). Rotifer resting egg deposition increased substantially, with values from $42.5 \times 10^{3}$ to $74.7 \times 10^{3}$ eggs.m $^{-2}$.year ${ }^{-1}$, in sections collected between 3-4 and 1-2 cm, over the period from ca. 1952 to 1992, during which lake acidification occurred and before the lake was limed (1989-1990; Fig. 1, panels 1-3).

A total of 12 different morphotypes of rotifer resting eggs were recovered from the sediment core. MT6 eggs were numerically dominant, accounting for between 60 and $90 \%$ of accumulated rotifer resting eggs in the $1-3 \mathrm{~cm}$ sections. Most such resting eggs were empty ( $>80 \%$ ), as open cases were typically observed. While total accumulation of eggs increased during the pollution phase, only five other resting egg taxa were recovered (i.e., MT1, MT2, MT4, MT5 and MT10; Appendix 1 available online), usually at much lower abundances (Fig. 3, panel 3). Correlation between the number of resting eggs' morphotypes and copper concentration in sediment sections resulted significant $(P<0.05$; Spearman $r=0.74 ; n=8$; Levene test for normality $=$ N.S. $)$.

Egg diversity decreased sharply during the pollution phase, with the minimum in the $2-3 \mathrm{~cm}$ section $(H=0.60)$. It increased sharply in the top $2 \mathrm{~cm}$ sections of the core, during the lake's recovery phase, reaching a maximum in the surficial layer, higher even than during the prepollution phase $(H=2.34$ versus 1.95 , respectively $)$. Evenness, however, remained lower than that calculated from the pre-pollution phase $(0.74$ versus 0.95 , respectively).

A comparison of rotifer resting egg composition before, during and after the pollution phase reveals that six morphotypes appeared only during the recovery (i.e., MT1, MT2, MT3, MT9, MT10 and MT11; Appendix 1). The post-pollution period resulted significantly different from pre- and during pollution phases (Scheffé test: $P=$ 0.0009 and $P=0.0015$, respectively).

Cladocera ephippia began to accumulate in the sediment cores later than rotifer resting eggs (by ca. 30 years ago), reaching levels of $8.5 \times 10^{3}$ and $11 \times 10^{3}$ ephippia.m ${ }^{-2}$.year ${ }^{-1}$ at sections $0-1$ and $1-2 \mathrm{~cm}$, respectively (Fig. 3, panel 4). Most recovered cladoceran resting eggs were from Daphnia ephippia, although Ceriodaphnia, Bosmina and Eubosmina were also found at lower levels of abundance (Fig. 3, panel 4). 


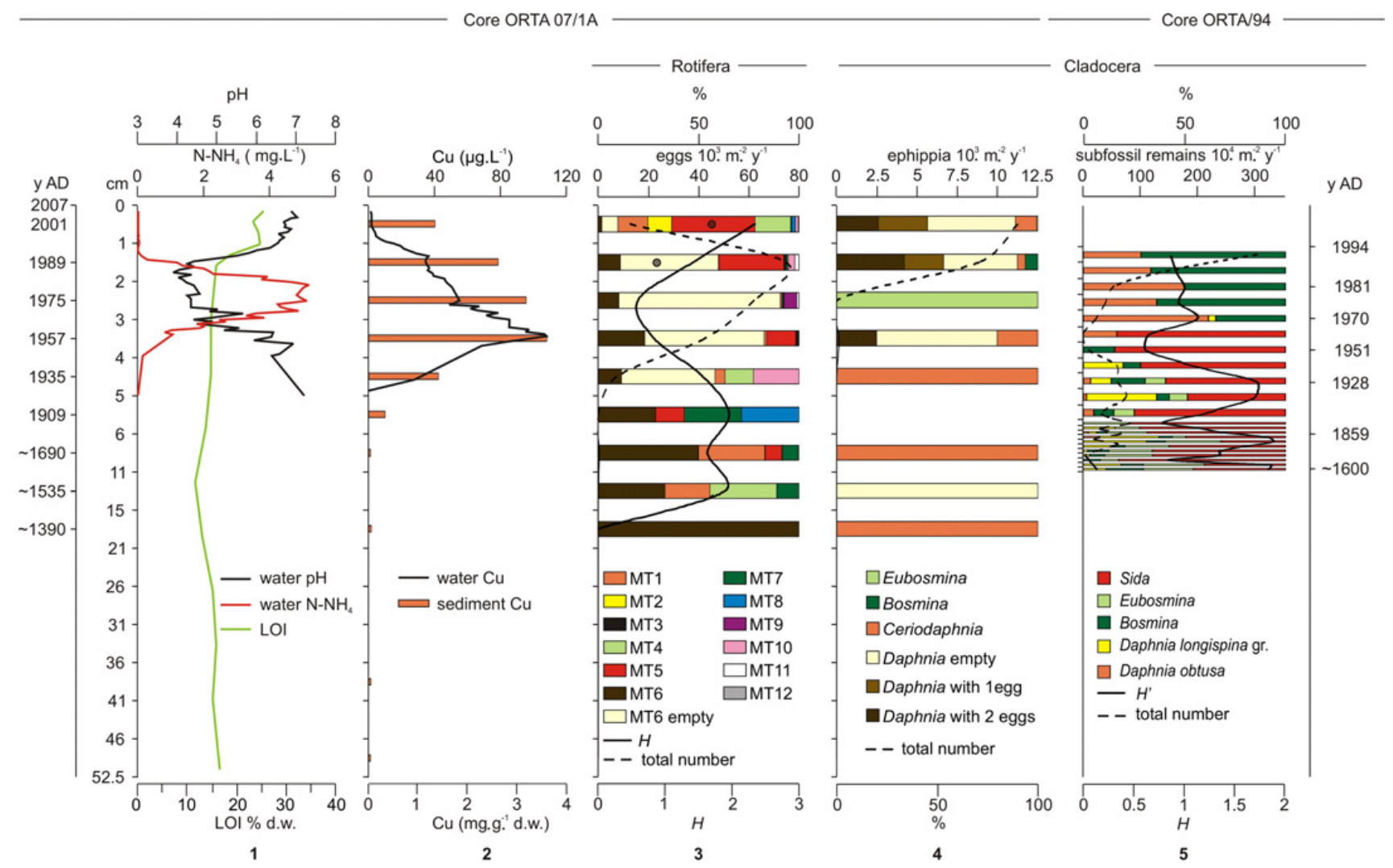

Fig. 3. (1) Organic matter (LOI) profile in sediment core ORTA 07/1A, along with changes in water pH and $\mathrm{N}-\mathrm{NH}_{4}$ concentrations; (2) comparison between total copper concentration in the water column and in the sediment core; (3) changes in accumulation rates and in diversity of rotifer resting eggs (the two dots indicating $H$ diversity index calculated from data on rotifers in the water column in 1989 and 2000; MT: morphotype); (4) changes in accumulation rates and diversity of Cladocera ephippia; (5) subfossil remains of Cladocera (only planktonic taxa, calculated from previous data on core ORTA/94; Manca and Comoli, 1995).

Daphnia ephippia of the recovery phase were morphologically different from the few detected before and during pollution. They included empty, 1-egg and 2-egg types (Fig. 3, panel 4). While empty ephippia prevailed in the youngest sediment section, and $50 \%$ of their total was of 1-egg, in the 1-2 $\mathrm{cm}$ section the proportion of empty ephippia was the same as that of 2-egg ones. Overall, the number of Daphnia ephippial eggs deposited in the $0-1$ and $1-2 \mathrm{~cm}$ core sections was fairly constant, at $7 \times 10^{3}$ eggs.cm ${ }^{-2}$. year $^{-1}$.

Ephippial and rotifer resting eggs were recovered from ORTA07/1A sediment core sections dating back to the 1400s (Fig. 3, panels 3 and 4), produced by Ceriodaphnia sp. and MT6. The oldest viable egg tested (i.e., from the upper $6 \mathrm{~cm}$ section of the core; $c f$. Materials and methods section) was of $B$. calyciflorus, and was deposited about $98 \pm 11$ years ago. The oldest viable ephippial egg recorded were produced by Bosmina longirostris and Daphnia sp. and deposited about $18 \pm 3$ years ago. Viable Polyarthra dolichoptera eggs were younger still, dating back to between 2007 and 1999 (i.e., they were $\leq 11$ years old).

While Cladocera egg bank was almost entirely depleted during pollution (Fig. 3, panel 5; Manca and Comoli, 1995), Rotifera were seemingly able to persist through the production of resting eggs (Brett, 1989; Havas et al., 1995). The increased accumulation was accompanied by a decrease in diversity and morphotype richness, thus suggesting strong selection for copper tolerance.

Hatching success was higher for ephippial eggs from 1 to $2 \mathrm{~cm}$ than for those from the topmost section of the core (37 versus $5 \%$, respectively). In the topmost section only those from 2-egg ephippia were still viable; those of the 1-2 $\mathrm{cm}$ section were more viable when from 1-egg ephippia (Table 3). Hatching success was variable in surficial sediments. For example, up to $75 \%$ of $B$. longirostris from the 1-2 cm section were viable, whereas only $25 \%$ of Ceriodaphnia sp. ephippial eggs from the $0-1 \mathrm{~cm}$ were likewise viable.

Rotifer resting eggs were found in nine sections of the core (Fig. 3, panel 3). Those of MT6 from sections 5-6 cm (corresponding to $c a$. 100 years BP) and $1-2$ and $0-1 \mathrm{~cm}$ sections were still viable. In all cases, hatched individuals could be identified as B. calyciflorus (Table 3). Up to $100 \%$ of $B$. calyciflorus resting eggs from sections $0-1$ and $5-6 \mathrm{~cm}$ sections were viable, though this value was reduced to only $5 \%$ for eggs from 1 to $2 \mathrm{~cm}$ section of the core. $P$. dolichoptera resting eggs recovered from the surface layer were also able to hatch, though success was relatively low $(11 \%)$. 
Table 3. Percentage of hatching success for resting eggs of Cladocera and rotifers in core ORTA 07/1A.

\begin{tabular}{|c|c|c|c|c|c|c|c|}
\hline \multirow[b]{2}{*}{ Depth $(\mathrm{cm})$} & \multirow[b]{2}{*}{ Age (AD) } & \multicolumn{2}{|c|}{ Daphnia sp. } & \multirow[b]{2}{*}{ Bosmina longispina } & \multirow[b]{2}{*}{ Ceriodaphnia sp. } & \multirow[b]{2}{*}{ B. calyciflorus } & \multirow[b]{2}{*}{ P. dolichoptera } \\
\hline & & 2 eggs ephippia & 1 egg ephippia & & & & \\
\hline $0-1$ & $2001 \pm 2$ & 8 & 0 & 0 & 25 & 100 & 11 \\
\hline $1-2$ & $1989 \pm 3$ & 36 & 41 & 75 & 0 & 5 & 0 \\
\hline $5-6$ & $1909 \pm 11$ & & & & & 100 & \\
\hline
\end{tabular}

\section{Genetic analyses}

All 28 resting eggs from $1-2$ to $4-5 \mathrm{~cm}$ layers gave clear and unambiguous reading for COI sequences; all COI sequences were identical and belonged to the same strain of B. calyciflorus. Sequences were deposited in GenBank with accession numbers from HQ331143 to HQ331170. DNA amplification was unsuccessful for the only egg from 5 to $6 \mathrm{~cm}$ layer.

\section{Discussion}

\section{Core chronology}

The sedimentation rate of core ORTA 07/1A (0.041 cm.year ${ }^{-1}$ ) was low, but consistent with that observed for other undisturbed, mountain lakes (Rose et al., 2011). Because of this, we were unable to resolve fine-scale temporal variation in this study. However, sedimentation was sufficient to allow reconstruction of changes in resting egg accumulation during Lake Orta's recent history of profound environmental disturbance, from the prepollution phase, through the period of intense copper, ammonium sulfate and lake acidification phase, to the recent recovery phase.

\section{Copper pollution}

Copper concentration was still high $\left(\sim 1.3 \mathrm{mg}^{-g^{-1}}\right.$ d.w.) in the $0-1 \mathrm{~cm}$ sediment section, suggesting that this metal might still being discharged into the lake. According to contemporary data on the water column, however, copper seems detectable at a very low concentration level (i.e., $<3 \mu \mathrm{g} . \mathrm{L}^{-1}$, value at the winter water mixing) as the lake is no more acidic. This apparent contrast may be explained by taking into account that copper and eventually other heavy metals accidentally released into the lake (Calderoni and Tartari, 2001), might promptly be captured by mineral particles and transported thereafter into lake sediments. This hypothesis is supported by the lake's unusually low total phosphorus concentration ( $<5 \mu \mathrm{g} . \mathrm{L}^{-1}$, during winter mixing) and its highly unusual phytoplankton composition and size relative to other deep subalpine lakes in the area (Morabito, 2001).

\section{Resting stages}

Accumulation of rotifer resting eggs increased much earlier than Cladocera ephippial eggs during the copper pollution phase; indeed, rotifer eggs were one order of magnitude higher in the 5-6 cm section than during the more recent pre-pollution section (10-11 cm; Fig. 3), dating back to the late 1600 s. The latter is remarkable, and we cannot exclude, given the low time resolution of the core, an effect of age on preservation of resting eggs.

Shannon-Weaver's $(H)$ diversity along the core was quite comparable to that based on subfossil remains of planktonic Cladocera ( $H^{\prime}$; Fig. 3, panel 5). Nevertheless, in the uppermost section of the core, diversity was maximum and slightly higher that measured at the base of the core, the lower evenness ( 0.74 versus 0.95 , data not shown) suggests that re-colonization of biota is still taking place. During the copper pollution phase, and particularly in the 2-4 cm sections of the sediment core, we found all taxa of rotifer resting eggs, although overall diversity was very low to the minimum observed ( $H$ from 0.30 to 0.19 ).

The appearance of non-indigenous Daphnia obtusa in 1986 (Fig. 3, panel 5; Manca and Comoli, 1995, modified) was tracked very well in ephippial and subfossil remains in the sediment (i.e., at 3-4 cm section of ORTA 07/1A and at 5-6 cm of ORTA/94; cf. Fig. 3, panels 4 and 5). The sharp increase in planktonic Cladocera (Fig. 3, panel 5) coincides with the increase in rotifer accumulation rate in ca. 1970 and in type diversity.

The appearance of new morphotypes (i.e., MT2, MT3, MT9, MT10, MT11 and MT12) during the lake pollution is consistent with results previously obtained for Cladocera, which showed that the first species to colonize Lake Orta after its chemical recovery was non-indigenous (e.g., D. obtusa). In the case of rotifers, however, some resting egg morphotypes were found in both the pre- and post-phases of industrial pollution (namely, MT1, MT4, MT5, MT6, MT7 and MT8; Fig. 3, panel 4). Rotifera diversity calculated from living communities during 1989 and 2001 corresponds with increasing resting egg diversity in the top two sections of Orta sediments, which include the same years $(0-2 \mathrm{~cm}$, i.e., during the last $c a .20$ years; Fig. 3, panel 3). Shannon-Weaver's $(H)$ diversity recorded in the sediment sections are approximately twice those obtained from live communities resident in the water column. This pattern might result from the presence in the former of non-planktonic taxa and the fact that the method used for sampling rotifers in the water column may underestimate species diversity (Steinberg et al., 2009; Chick et al., 2010). In addition, intra-species variation in egg morphology can be pronounced in some taxa (e.g., Synchaeta; Gilbert, 1995).

Rotifer and cladoceran resting eggs were first detected in the sediment core at 20-21 cm depth (i.e., ca. 1390 AD). Cladocera are classified as subfossil remains and 
their degree of preservation depends on local sediment conditions (Frey, 1986), but we do not know whether older rotifer resting eggs were destroyed or not produced before that age. The concomitant appearance of Cladocera ephippia and rotifer resting eggs might be related to a shift in reproductive strategy or to the appearance of taxa clones capable of producing resting stages.

The accumulation of rotifer resting eggs began to increase and reached a maximum level earlier than that observed for ephippia and concomitant with the onset of copper discharge into the lake (in the middle $30 \mathrm{~s}$, i.e., at 4-5 cm section), which might be interpreted as a faster response of Rotifera to pollution. During pollution, Cladocera were almost completely depleted from Lake Orta (Manca and Comoli, 1995) and increase in ephippial eggs traces re-colonization after lake chemical recovery. On the other hand, hatched rotifer eggs (empty cases) suggest a persistence during copper pollution.

The accumulation of ephippial and rotifer resting eggs in core ORTA07/1A was within the range (from $10^{3}$ to $10^{6}$ eggs. $\mathrm{m}^{-2}$ ) commonly reported in both freshwater and marine sediments (Hairston, 1996), and quite comparable to those of oligotrophic sites. Higher egg densities, up to $4 \times 10^{7} \mathrm{~m}^{-2}$, have been detected in rotifer egg banks of eutrophic lakes (Nipkow, 1961; Duggan et al., 2002).

The oldest viable eggs of Rotifera of B. calyciflorus, were of a remarkable age, $c a$. 100 years old (pre-pollution phase), so far reported only for Brachionus plicatilis O.F. Müller (Fu, 1991).

The viability of eggs deposited after the onset of copper pollution, and which were buried in high-copper concentration sediment layers $\left(\mathrm{Cu}=1.3\right.$ and $2.6 \mathrm{mg} \cdot \mathrm{g}^{-1} \mathrm{~d} . \mathrm{w}$. in sections $0-1$ and 1-2 cm, respectively, Fig. 3, panel 2), suggests that hatching was not inhibited, unlike what was observed for parthenogenetic eggs of $B$. calyciflorus (Gama-Flores and Castellanos-Paez, 2007). These eggs were also unaffected by exposure to $\mathrm{Cu}^{2+}$ in the water column (when the lake was acid) at the time they were produced, indicating that physiological adaptation may provide important protection to adverse conditions for Lake Orta's rotifers, as observed for contemporary Daphnia (Ponti et al., 2010).

Ephippial eggs were viable only if they were produced comparatively in recent times (i.e., $<c a .20$ years). This value is typical for Cladocera ephippia, with a maximum age of 125 years being regarded as exceptional (Cáceres, 1998). These eggs, too, were able to hatch after exposure to high levels of copper in Lake Orta's sediments, levels far higher than those reported to inhibit hatching of Daphnia ephippial eggs (i.e., 1.3 and $2.6 \mathrm{mg} . \mathrm{g}^{-1} \mathrm{~d}$.w., with respect to $0.7 \mathrm{mg} . \mathrm{g}^{-1}$; Kerfoot et al., 1999). Furthermore, viability of Daphnia was not related to the presence of 1 or 2 eggs in the ephippium.

\section{Genetic analyses}

Previous research on Lake Orta indicated that not only was the D. obtusa colonist that followed lake recovery a non-indigenous species, but the genetic homogeneity of its population suggests it belonged to a single, re-colonizing clone (Bachiorri et al., 1991), able to grow best in the peculiar environment of the early recovery phase of the lake. The species that colonized the lake later on, when $\mathrm{pH}$ had returned close to neutrality, also appeared to be better able to tolerate copper exposure than species living in nonpolluted environments (Ponti et al., 2010).

DNA extraction was successful for all eggs deposited between sections 4-5 and 1-2 cm of core ORTA 07/1A, which correspond to a period between $1935 \pm 7$ and $1989 \pm 3$ year AD, i.e., during the pollution and the recovery phase, but not before the pollution onset. We expected to find peculiar strains and/or a strong selection for rotifers during the pollution phase or at least a change in strain during the recovery phase, as was the case for Daphnia. Surprisingly, however, the results of DNA analysis revealed that $B$. calyciflorus analyzed during the pollution and recovery phases belonged to a single mitochondrial strain. Thus, no new clones appear to have colonized the lake after pollution abatement occurred. The mitochondrial strain found in Lake Orta is a common and widespread one, already known from both North America and Asia (Gilbert and Walsh, 2005; Li et al., 2010). The fact that only one strain was found is rather surprising, as the only other genetic analysis of B. calyciflorus at the population level revealed that usually more than six strains co-occur in a water body from China at any time (Li et al., 2010). Lake Orta may thus be a peculiar lake, where only one of the strains of B. calyciflorus could and does thrive.

\section{Conclusions}

This is a first attempt to reconstruct changes in rotifer diversity on a centennial timescale using resting eggs from a sediment core for a comparison with Cladocera ephippia.

- Rotifera resting eggs and ephippia appeared in the sediment $c a$. 4 centuries ago. We cannot infer, however, whether they might also have been present (but not preserved) from earlier periods.

- Resting eggs of rotifers started to increase in numbers during intense copper pollution in the lake, earlier than ephippia, which increased only during the recovery. Similar to what previously reconstructed from Cladocera subfossil remains, rotifer resting egg diversity decreased during pollution because of the dominance of few types. The appearance and increase of empty egg cases of Brachionus sp. suggest attempts to start an active population in the water column during this phase.

- As expected, resting eggs diversity was higher than that based on contemporary plankton data, as a result of both intraspecific polymorphism and a possible contribution from non-planktonic taxa. The two estimates, however, were comparable in terms of changes with time. 
- Viability of B. calyciflorus resting eggs was high, fully comparable to that reported from laboratory experiments using contemporary parthenogenetic eggs. The presence of $c a$. 100-year-old eggs fully viable, suggested that they were unaffected by the toxic environment in which they were released and deposited. This result indicates a greater ability of resting eggs to tolerate exposure to high copper concentrations, in contrast to parthenogenetic eggs which, as reported in the literature, reduce hatching success when exposed to copper concentrations lower than those measured in Lake Orta's sediments.

- Unexpectedly, we found that B. calyciflorus present from pre- to post-pollution phase belonged to the most commonly distributed North American clone, suggesting a physiological adaptation to high levels of copper.

- Overall, Cladocera ephippia appeared less represented during lake historical changes.

\section{References}

Appleby P.G., 2002. Chronostratigraphic techniques in recent sediments. In: Last W.M. and Smol I.P. (eds.), Tracking Environmental Change Using Lake Sediments. Volume 1. Springer Netherlands, 171-223.

Appleby P.G. and Oldfield F., 1978. The calculation of lead-210 dates assuming a constant rate of supply of unsupported ${ }^{210} \mathrm{~Pb}$ to the sediments. Catena, 5, 1-8.

Appleby P.G., Nolan P.J., Gifford D.W., Godfrey M.J., Oldfield F., Anderson N.J. and Battarbee R.W., 1986. ${ }^{210} \mathrm{~Pb}$ dating by low background gamma counting. Hydrobiologia, 141, 21-27.

Appleby P.G., Richardson N. and Nolan P.J., 1992. Selfabsorption corrections for well-type germanium detectors. Nucl. Instrum. Methods B, 71, 228-223.

Bachiorri A., Rossi V. and Menozzi P., 1991. Differences in demographic parameters among electrophoretric clones of Daphnia obtusa Kurz (Crustacea, Cladocera). Hydrobiologia, 225, 263-268.

Bonacina C. and Baudo R. (Guests eds), 2001. Lake Orta: a case study. J. Limnol., 60, 166 p.

Brett M.T., 1989. Zooplankton communities and acidification processes: a review. Water Air Soil Pollut., 44, 387-414.

Cáceres C.E., 1998. Interspecific variation in the abundance, production, and emergence of Daphnia diapausing eggs. Ecology, 79, 1699-1710.

Calderoni A., Mosello R., Quirci A. and de Bernardi R., 1990. Recovery of Lake Orta by liming. Proceedings of theVII International Lime Congress, Rome, September 13-14, 1990, 157-171.

Calderoni A. and Tartari G.A., 2001. Evolution of the water chemistry of Lake Orta after liming. J. Limnol., 60, 69-78.

Cattaneo A., Asioli A., Comoli P. and Manca M., 1998. Organisms' response in a chronically polluted lake supports hypothesized link between stress and size. Limnol. Oceanogr., 43, 1938-1943.

Chick J.H., Levchuk A.P., Medley K.A. and Havel J.H., 2010. Underestimation of rotifer abundance, a much greater problem than previously appreciated. Limnol. Oceanogr. Methods, 44, 79-87.
Dean W.E. Jr., 1974. Determination of carbonate and organic matter in calcareous sediments and sedimentary rocks by loss on ignition: comparison with other methods. J. Sed. Petrol., 44, 242-248.

Duggan I.C., Green J.D. and Russell J.S., 2002. Rotifer resting egg densities in lakes of different trophic state, and their assessment using emergence and egg counts. Arch. Hydrobiol., 153, 409-420.

Folmer O., Black M., Hoeh W., Lutz R. and Vrijenhoek R., 1994. DNA primers for amplification of mitochondrial cytochrome $c$ oxidase subunit 1 from diverse metazoan invertebrates. Mar. Biotechnol., 3, 294-299.

Frey D.G., 1986. Cladocera analysis. In: Berglund B.E. (ed.), Handbook of Holocene Paleoecology and Paleohydrobiology, Wiley and Sons, New York, 667-692.

$\mathrm{Fu}$ Y., 1991. Studies on genetic variations of the rotifer Brachionus plicatilis O.F. Müller. PhD Thesis, Nagasaki University, 144.

Gama-Flores J.L. and Castellanos-Paez M.E., 2007. Effect of pulsed exposure to heavy metals (copper and cadmium) on some population variables of Brachionus calyciflorus Pallas (Rotifera: Brachionide: Monogononta). Hydrobiologia, 593, 201-208.

Gilbert J.J., 1974. Dormancy in rotifers. Trans. Am. Microsc. Soc., 93, 490-512.

Gilbert J.J., 1980. Female polymorphism and sexual reproduction in the rotifer Asplanchna: evolution of their relationship and control by dietary tocopherol. Am. Nat., 116, 409-431.

Gilbert J.J., 1995. Structure, development and induction of a new diapause stage in rotifers. Freshwat. Biol., 34, 263-270.

Gilbert J.J. and Schröder T., 2004. Rotifers from diapausing, fertilized eggs: unique features and emergence. Limnol. Oceanogr., 49, 1341-1354.

Gilbert J.J. and Walsh E.J., 2005. Brachionus calyciflorus is a species complex: mating behavior and genetic differentiation among four geographically isolated strains. Hydrobiologia, $546,257-265$.

Hairston N.G. Jr., 1996. Zooplankton egg banks as biotic reservoirs in changing environments. Limnol. Oceanogr., 41, 1087-1092.

Hairston N.G. Jr., Van Brunt R.A., Kearns C.M. and Engstrom D.R., 1995. Age and survivorship of diapausing eggs in a sediment egg bank. Ecology, 76, 1706-1711.

Havas M., Woodfine D.G., Lutz P., Young K., MacIsaac H.I. and Hutchinson T.C., 1995. Biological recovery of two previously acidified, metal-contaminated lakes near Sudbury Ontario, Canada. Water Air Soil Pollut., 85, 791-796.

Jeppesen E., Jensen J.P., Lauridsen T.L., Amsinck S.L., Christoffersen K., Søndergaard M. and Mitchell S.F., 2003. Sub-fossils of cladocerans in the surface sediment of 135 lakes as proxies for community structure of zooplankton, fish abundance and lake temperature. Hydrobiologia, 491, 321-330.

Kerfoot W.C., Robbins J.A. and Weider L.J., 1999. A new approach to historical reconstruction: combining descriptive and experimental paleolimnology. Limnol. Oceanogr., 44, 1232-1247.

Kirk K.L., 1997. Life-history responses to variable environments: starvation and reproduction in planktonic rotifers. Ecology, 78, 434-441.

Koste W., 1978. Rotatoria. Die Rädertiere Mitteleuropas. Ein Bestimmungswerk, begründet von Max Voigt. Überordnung 
Monogononta 2. Gebrüder Borntraeger, Berlin, Stuttgart, 673.

Li L., Niu C. and Ma R., 2010. Rapid temporal succession identified by COI of the rotifer Brachionus calyciflorus Pallas in Xihai Pond,Beijing, China, in relation to ecological traits. J. Plankton Res., 32, 951-959.

Manca M. and Comoli P., 1995. Temporal variations of fossils Cladocera in the sediments ofLake Orta (N. Italy) over the last 400 years. J. Paleolimnol., 14, 113-122.

Morabito G., 2001. Six years (1992-1997) evolution of phytoplankton communities inLake Orta (N. Italy) after the recovery by liming. Lakes Reserv. Res. Manage. 6, 305-312.

Nevalainen L., Luoto T.P., Levine S. and Manca M., 2011. Paleolimnological evidence for increased sexual reproduction in chydorids (Chydoridae, Cladocera) under environmental stress. J. Limnol., 70, 255-262.

Nipkow F., 1961. Die Rädertiere im Plankton des Zürichsees und ihre Entwicklungsphasen. Schweiz Z. Hydrol., 23, 398-461.

Onbé T., 1978. Sugar flotation method for sorting the resting eggs of marine Cladocerans and Copepods from sea-bottom sediment. Bull. Jpn. Soc. Fish. Oceanogr., 44, 1411.
Pielou E.C., 1966. Species-diversity and pattern-diversity in the study of ecological succession. J. Theor. Biol., 10, 370-383.

Ponti B., Piscia R., Bettinetti R. and Manca M., 2010. Long-term adaptation of Daphnia to toxic environment in Lake Orta: the effects of short-term exposure to copper and acidification. J. Limnol., 69, 217-224.

Rose N.L., Morley D., Appleby P.G., Battarbee R.W., Alliksaar T., Guilizzoni P., Jeppesen E., Korhola A., Punning J.-M., 2011. Sediment accumulation rates in European lakes since AD 1850: trends, reference conditions and exceedence. J. Paleolimnol., 45, 447-468.

Sarmaja-Korjonen K., 2004. Chydorid ephippia as indicators of past environmental changes - a new method. Hydrobiologia, 526, 129-136.

Shannon C.E. and Wiener W., 1963. The Mathematical Theory of Communities. University of Illinois Press, Urbana, IL, USA, 117.

Steinberg A., Ejsmont-Karabin J., Muirhead J.R. and MacIsaac H.J., 2009. Spatial and temporal stability of rotifer communities. Hydrobiologia, 624, 107-114.

Sudzuki M., 1964. New systematical approach to the Japanese planktonic Rotatoria. Hydrobiologia, 23, 1-124. 